\title{
Pola Asuh Orang Tua dan Motivasi Belajar Berhubungan Erat terhadap Hasil Belajar IPA
}

\section{N.L Chintya Sari1 ${ }^{*}$, I Komang Sudarma ${ }^{2}$, I Gusti Ngurah Japa ${ }^{3}$}

1,2,3 Program Studi Pendidikan Guru Sekolah Dasar, Universitas Pendidikan Ganesha, Indonesia

\section{ART I C LE IN F O}

\section{Article history:}

Received June 25, 2021

Revised June 26, 2021

Accepted September 25, 2021

Available online October 25, 2021

Kata Kunci:

Pola Asuh, Motivasi, Hasil Belajar

\section{Keywords:}

Parenting Patterns, Motivation, Learning Outcomes.

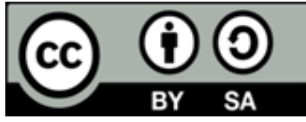

This is an open access article under the CC BY-SA license.

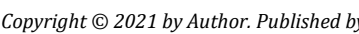
Universitas Pendidikan Ganesha.

\begin{abstract}
A B S T R A K
Kendala yang dialami orangtua dalam membimbing anak untuk belajar dapat berpengaruh terhadap rendahnya motivasi dan hasil belajar IPA siswa khususnya pada muatan IPA. Penelitian ini bertujuan untuk mengkaji hubungan antara pola asuh orangtua dan motivasi belajar terhadap hasil belajar siswa. Jenis penelitian ini adalah penelitian expost facto. Jumlah sampel dalam penelitian ini adalah 143 siswa. Teknik pengambilan data dengan menggunakan kuesioner. Analisis data yang digunakan adalah regresi sederhana dan regresi ganda dengan menggunakan SPSS. Hasil penelitian menunjukkan pola asuh orangtua, motivasi belajar, dan hasil belajar saling mempengaruhi. Apabila dijabarkan adalah sebagai berikut; pertama terdapat hasil yang signifikan antara pola asuh dengan hasil belajar yang diperoleh nilai $F_{\text {hitung }}>F_{\text {tabel }}(0,908>0,163)$, kedua terdapat hubungan signifikan antara motivasi dengan hasil belajar yang diperoleh nilai $F_{\text {hitung }}>F_{\text {tabel }}(0,166>0,163)$, ketiga terdapat hubungan signifikan antara pola asuh dan motivasi terhadap hasil belajar IPA yang diperoleh nilai $F_{\text {hitung }}$ $>F_{\text {tabel }}(0,166>0,163)$. Jadi, terdapat hubungan yang signifikan antara pola asuh orang tua dan motivasi belajar terhadap hasil belajar IPA siswa Kelas $\checkmark$ Sekolah Dasar secara terpisah dan simultan. Penelitian ini berdampak terhadap perbaikan berupa upaya orangtua, guru, dan masyarakat untuk menanamkan konsep diri yang positif terhadap anak melalui pola asuh yang baik untuk meningkatkan motivasi belajar dan hasil belajar siswa.
\end{abstract}

\section{A B S T R A C T}

Obstacles experienced by parents in guiding children to learn can affect the low motivation and learning outcomes of students' science, especially on science content. This study aims to examine the relationship between parenting and learning motivation on student learning outcomes. This type of research is ex post facto research. The number of samples in this study was 143 students. Data collection techniques using a questionnaire. The data analysis used is simple regression and multiple regression using SPSS. The results showed that parenting, learning motivation, and learning outcomes influence each other. When described are as follows; First, there are significant results between parenting and learning outcomes obtained by the value of $F_{\text {count }}>F_{\text {table }}(0.908>0.163)$, secondly there is a significant relationship between motivation and learning outcomes obtained by the value of $F_{\text {count }}>F_{\text {table }}(0.166>0.163)$, thirdly, there is a significant relationship between the pattern nurturing and motivation on science learning outcomes obtained by the value of $F_{\text {count }}>F_{\text {table }}(0.166>0.163)$. So, there is a significant relationship between parenting patterns and learning motivation on science learning outcomes for Grade V Elementary School students separately and simultaneously. This research has an impact on improvements in the form of efforts by parents, teachers, and the community to instill a positive self-concept in children through good parenting to increase learning motivation and student learning outcomes.

\section{PENDAHULUAN}

Penanaman konsep-konsep dasar IPA dalam pembelajaran muatan IPA pada jenjang sekolah dasar bertujuan agar siswa mengetahui lingkungan sekitar serta dapat memecahkan masalah terkait kejadian alam yang sering terjadi. Ketertarikan siswa dalam mengikuti proses pembelajaran memerlukan bimbingan dalam belajar sehingga siswa memiliki minat dan motivasi untuk belajar. Pada pembelajaran IPA seharusnya siswa aktif dalam pembelajaran serta diberikan kesempatan untuk mengalami dan menemukan sendiri tentang makna dari materi yang diajarkan (Lusidawaty et al., 2020; Mahmud et al., 2018; Meo et al., 2021; Prananda et al., 2020). Pembelajaran IPA diharapkan dapat menjadi ajang bagi siswa untuk mempelajari dirinya sendiri dan alam 
sekitar, sehingga siswa dapat menerapkannya dalam kehidupan sehari-hari (Fransisca \& Mintohari, 2018). Namun tanpa adanya bimbingan dari orang-orang sekitar siswa yang mempu mendorong semangat belajar siswa akan berpengaruh terhadap rendahnya hasil belajar siswa. Oleh karena itu, selain bimbingan guru dalam meningkatkan hasil belajar siswa diperlukan pola asuh yang baik dari orangtua untuk memotivasi siswa dalam belajar khususnya dalam pembelajaran IPA. Pola asuh orangtua sangat berpengaruh terhadap pertumbuhan dan perkembangan anak baik dari segi fisik, sifat, kepribadian, konsep diri, inteligensi, sosial dan emosional anak (Budiarnawan et al., 2014; Tarmidzi, 2018). Bimbingan yang tepat dari pola asuh orang tua dapat meningkatkan motivasi belajar siswa sehinnga tumbuh dorongan dalam diri siswa untuk belajar dengan semangat tinggi menggunakan semua kemampuan dan keterampilan yang dimiliki dirinya (Dewi et al., 2020; Sunarsi, 2018). Jadi, untuk meningkatkan kualitas pembelajaran muatan IPA, pola asuh orangtua dan motivasi siswa sangat berperan penting guna meningkatkan hasil belajar siswa.

Namun, pada kenyataannya fenomena yang terjadi di sekolah dasar adalah siswa mengalami penurunan hasil belajar dikarenakan kurangnya motivasi belajar, mereka cenderung malas belajar karena kurangnya interaksi dengan ligkungan sekolah khususnya dalam pembelajaran IPA. Sependapat dengan kebanyakan anak pada masa seperti ini akan bersentuhan dengan teknologi arena teknologi dianggap lebih berwarna dari pada berinteraksi dengan lingkungan sekitar mereka (Safitri et al., 2020). Hal ini ditunjukkan dengan hasil PISA (the programme for international student assessment) pada tahun 2018 yang dipublikasikan oleh Organization for Economic Cooperation and Development (OECD) menyatakan bahwa kategori kemampuan sains Indonesia berada di peringkat ke 71 dari 79 negara partisipan PISA dengan skor rata-rata 389 yang berada di bawah skor rata-rata Internasional yakni 500 (Hewi \& Shaleh, 2020). Hal ini terjadi karena adanya masalah dalam pembelajaran IPA yang mengakibatkan rendahnya hasil belajar siswa. Salah satu masalah dalam pembelajaran IPA adalah kurangnya bimbingan serta pola asuh yang tidak tepat dari orangtua (Pucangan et al., 2017; Widiantari \& Suarjana, 2020). Setelah melakukan wawancara dengan guru kelas selain orang tua yang sibuk karena pekerjaannya dan motivasi belajar yang kurang saat belajar dirumah, pola asuh orang tua belum sesuai dengan apa yang diperlukan anaknya. Orang tua kurang berkomunikasi dengan anaknya tentang pendidikan disekolah, lebih memanjakan anaknya dengan mengikuti kemauan anaknya. Pola asuh yang kurang baik terhadap anak akan menyebabkan menurunnya motivasi belajar siswa dan rendahnya hasil belajar siswa (Fitasari et al., 2019). Hal ini apabila tidak segera ditanggulangi akan berdampak pada rendahnya kualitas sumber daya manusia dan kualitas pembelajaran IPA di Indonesia kedepannya.

Faktor-faktor yang mempengaruhi hasil belajar terdiri dari dua faktor yakni faktor internal dan eksternal. Faktor internal adalah faktor yang berasal dari dalam diri individu yang bersangkutan, yaitu; keadaan fisik dan psikis contohnya seperti gaya belajar, motivasi belajar, konsentrasi, raya percaya diri, intelegensi, kebiasaan belajar, dan lain-lain. Sedangkan faktor eksternal merupakan faktor yang berasal dari luar individu yang bersangkutan atau lingkungannya contohnya keluarga, sarana dan prasarana, kurikulum, dan lain-lain (Sari, 2014). Faktor internal yang paling berperan merupakan motivasi belajar, karena motivasi belajar yang kuat dapat mendorong siswa belajar tekun sehingga dapat mewujudkan hasil belajar siswa yang hendak dicapai (Maswin et al., 2020). Motivasi siswa dalam pembelajaran ditunjukkan oleh sikap siswa dalam proses pembelajaran yang meliputi; minat, semangat, tanggung jawab, rasa senang dalam mengerjakan tugas dan reaksi yang ditunjukkan siswa terhadap stimulus yang diberikan guru (Rizqi \& Sumantri, 2019). Faktor-faktor yang mempengaruhi motivasi belajar siswa adalah kemampuan siswa, kondisi lingkungan siswa, dan upaya guru dalam membelajarkan siswa (Moslem et al., 2019; Sabrina et al., 2017). Selain itu, faktor yang mempengaruhi motivasi belajar adalah faktor internal dan faktor eksternal. Faktor internal berupa kesadaran diri atas pemahaman betapa pentingnya belajar untuk mengembangkan dirinya dan bekal untuk menjalani kehidupan, dan faktor eksternal yaitu dapat berupa rangsangan dari orang lain atau lingkungan sekitarnya yang dapat mempengaruhi psikologis orang yang bersangkutan. Dalam faktor eksternal berupa kondisi lingkungan siswa, peningkatan motivasi belajar siswa tentunya tidak terlepas dari pola asuh orangtua sebagai tempat utama siswa belajar.

Sejak kecil anak-anak sudah mendapatkan pendidikan dari orangtua dengan penanaman sikap sebagai cerminan pendidikan yang diberikan oleh orangtua. Pola asuh orang tua sangat mencerminkan keharmonisan keluarga dalam mendidik anaknya, anak yang mendapat pola asuh yang baik akan membentuk pribadi anak yang optimal baik secara fisik, intelektual, dan psikisnya (Budiarnawan et al., 2014; Tarmidzi, 2018). Sikap orang tua dalam berinteraksi, membimbing, membina, dan mendidik dalam kehidupan sehari-hari menentukan kesuksesan anaknya menjalani kehidupan (Juniarti et al., 2020). Secara umum pola asuh orang tua dalam keluarga di bedakan menjadi tiga jenis yaitu pola asuh otoriter, pola asuh demokratis dan pola asuh permisif. 1) pola asuh otoriter yaitu pola asuh yang memaksakan anaknya untuk mengikuti atau mentaati aturan dari orang tua terkadang orang tua memberikan hukuman jika anak melanggar aturan yang telah dibuatnya. 2) pola asuh demokratis yaitu pola asuh yang memberi kebebasan pada anaknya namun anak dan orang tua tetap mengetahui hak dan kewajiban masing-masing, dimana orang tua memberikan kesempatan pada anak untuk mencari jati dirinya dan didukung oleh orang tuanya. 3) pola asuh permisif yaitu pola asuh yang membebaskan anaknya untuk berperilaku sesuai keinginannya dan orang tua tidak memberikan hukuman atau teguran meskipun sudah 
tidak sesuai aturan (Desta et al., 2014; Machmud, 2018). Faktor-faktor yang mempengaruhi pola asuh orangtua meliputi; jenis kelamin anak, kepribadian orangtua, keyakinan, status sosial ekonomi, dan persamaan dengan pola asuh yang diterima orangtua (Adawiah, 2017; Khodijah, 2018).

Pentingnya pola asuh dan motivasi belajar terhadap hasil belajar siswa memerlukan kerjasama serta komunikasi yang baik oleh guru dan orangtua siswa. Penelitian yang pernah yang menyatakan bahwa terdapat hubungan yang signifikan antara pola asuh orangtua dan motivasi belajar siswa terhadap hasil belajar siswa(Dewi et al., 2020; Rizqi \& Sumantri, 2019; Wulandari \& Renda, 2020). Berdasarkah hal tersebut, untuk mengetahui sejauh mana hubungan antra pola asuh orang tua dan motivasi belajar terhadap hasil belajar IPA, maka perlu dilakukan pengkajian hubungan pola asuh orang tua dan motivasi belajar terhadap hasil belajar IPA. Tujuan penelitian ini adalah untuk mengkaji hubungan antara pola asuh orang tua dan motivasi belajar terhadap hasil belajar siswa. Tujuan tersebut dapat tercapai melalui kajian hubungan antara pola asuh orangtua dengan hasil belajar, hubungan antara motivasi belajar dengan hasil belajar, dan hubungan antara pola asuh orang tua dan motivasi belajar..

\section{METODE}

Penelitian ini berjenis penelitian expost facto yang mengkaji keterkaitan antara pola asuh orangtua dan motivasi belajar siswa terhadap hasil belajar siswa pada muatan IPA. Dalam penelitian ini yang menjadi variabel bebas adalah pola asuh orang tua dan motivasi belajar, sedangkan variabel terikatnya adalah hasil belajar IPA siswa. Penelitian expost facto merupakan pendekatan tanpa suatu perlakuan guna memunculkan variabel yang ingin diteliti pada subjek penelitian (Rizqi \& Sumantri, 2019; Juniarti et al., 2020). Penelitian expost fakto bertujuan untuk mengungkap hubungan dua variabel atau lebih tanpa manipulasi (Sugiartini et al., 2019; Wulandari \& Renda, 2020). Penelitian ini dilakukan di SD Gugus VIII Kecamatan Buleleng pada kelas V dengan jumlah populasi sebanyak 169 siswa. Populasi adalah himpunan dari unsur-unsur yang sejenis (Koyan, 2012). Dalam populasi terdapat wilayah generalisasi yang terdiri atas objek/subjek yang mempunyai kualitas dan karakteristik tertentu yang ditetapkan oleh peneliti untuk dipelajari dan kemudian ditarik kesimpulan (Sugiyono, 2010). Jadi populasi adalah seluruh siswa yang akan diteliti. Selain populasi dalam penelitian ini menggunakan sampel. Sampel ialah sebagian dari populasi yang diambil, yang dianggap mewakili populasi dan diambil dengan menggunakan teknik tertentu (Agung, 2014; Anggraini et al., 2017). Dengan demikian sampel adalah sebagian dari populasi yang ditentukan oleh peneliti untuk dipelajari dan kemudian ditarik kesimpulan. Dalam penelitian ini sampel diambil menggunakan teknik sampling random. Dari teknik tersebut maka ditetapkan jumlah sampel penelitian yakni 143 siswa.

Metode pengumpulan data dilakukan untuk mencari data pendukung dalam sebuah penelitian. Metode yang digunakan dalam penelitian ini meliputi data pola asuh, data motivasi dan data hasil belajar. Metode yang digunakan dalam pengumpulan menggunakan metode pencatatan dokumen untuk hasil belajar dan metode pengumpulan data pola asuh dan motivasi menggunakan metode non tes. Metode non tes berupa kuesioner/angket. Metode kuesioner/angket merupakan cara memperoleh atau mengumpulkan data dengan mengirimkan suatu daftar pertanyaan/pernyataan- pernyataan kepada responden/subjek penelitian (Agung, 2014). Jadi kuesioner dapat diartikan teknik yang menggunakan sebuah pernyataan-pernyataan yang nantinya dijawab oleh responden dengan tujuan mengumpulkan keterangan sesuai dengan kenyataan atau data yang berkaitan dengan penelitian. Kisi-kisi hasil validitas instrument pada pola asuh orang tua adalah peduli terhadap kebutuhan anak, menghargai anak, memberikan waktu luang kepada anak, menjalin komunikasi yang baik dengan anak, memberikan kebebasan pada anak namun tetap ada pengawasan, menuntut anak secara berlebihan, menunjukkan sikap tidak mencintai anak, sering memberikan hukuman pada anak, anak dipaksa menuruti kemauan orang tua, tidak memperdulikan anak. Kisi-kisi hasil validitas instrumen pada motivasi belajar adalah memiliki keinginan yang tinggi untuk sukses dalam belajar, bersemangat dalam melakukan aktivitas belajar, mengutamakan kegiatan belajar dari pada kegiatan lain, tidak mudah terganggu oleh kegiatan orang lain, tekun dalam mengerjakan tugas, pantang menyerah, suka melakukan aktivitas belajar dalam waktu yang lama. Kisi-kisi intrumen pola asuh orang tua disajikan pada Tabel 1 dan kisi-kisi instrumen motivasi belajar disajikan pada Tabel 2. Teknik analisis data yang digunakan adalah analisis regresi dengan menggunakan bantuan dari aplikasi SPSS 20. Pada saat pengujian hipotesis I yang berbunyi "hubungan yang signifikan pola asuh orang tua dengan hasil belajar IPA siswa" menggunakan analisis regresi sederhana, pengujian hipotesis II yang berbunyi" hubungan yang signifikan motivasi belajar dengan hasil belajar IPA siswa" menggunakan analisis regresi sederhana, sedangkan pengujian hipotesis III yang berbunyi hubungan yang signifikan pola asuh orang tua dan motivasi belajar dengan hasil belajar IPA siswa" menggunakan analisis regresi ganda. 
Tabel 1. Kisi-Kisi Instrumen Pola Asuh Orang Tua

\begin{tabular}{llllll}
\hline Variabel & $\begin{array}{c}\text { Aspek Pola } \\
\text { Asuh Orang }\end{array}$ & \multicolumn{1}{c}{ Indikator } & \multicolumn{2}{c}{ Butir Soal } & Jumlah \\
& \multicolumn{1}{c}{ Tua } & & Positif & Negatif & Butir \\
\hline Pola & Pola Asuh & Peduli terhadap kebutuhan anak & 1,2 & 3 & 3 \\
Asuh & Menerima & Menghargai anak & 4,5 & 6 & 3 \\
Orang & (acceptance) & Memberikan waktu luang kepada anak & 7 & 8,9 & 3 \\
Tua & anaknya & Menjalin komunikasi yang baik dengan anak & 10,11 & 12 & 3 \\
& & Memberikan kebebasan pada anak namun & 13 & 14,15 & 3 \\
& & tetap ada pengawasan & 16,17 & 18 & 3 \\
& Pola Asuh Yang & Menuntut anak secara berlebihan & 19 & 20,21 & 3 \\
& menolak & Menunjukkan sikap tidak mencintai anak & 22,23 & 24 & 3 \\
& (Rejection) & Sering memberikan hukuman kepada anak & 26 & 3 \\
& anaknya & Anak dipaksa menuruti kemauan orang tua & 25 & 26,27 & 3 \\
& & Tidak memperdulikan anaknya & 28,29 & 30 & 3 \\
\hline
\end{tabular}

Tabel 2. Kisi-Kisi Instrumen Motivasi Belajar

\begin{tabular}{|c|c|c|c|c|c|}
\hline \multirow{2}{*}{ Variabel } & \multirow{2}{*}{$\begin{array}{l}\text { Aspek Motivasi } \\
\text { Belajar }\end{array}$} & \multirow{2}{*}{ Indikator } & \multicolumn{2}{|c|}{ Butir Soal } & \multirow{2}{*}{$\begin{array}{c}\text { Jumlah } \\
\text { Butir }\end{array}$} \\
\hline & & & Positif & Negatif & \\
\hline \multirow[t]{7}{*}{$\begin{array}{l}\text { Motivasi } \\
\text { Belajar }\end{array}$} & Mendorong & $\begin{array}{l}\text { Memiliki keinginan yang tinggi untuk } \\
\text { sukses dalam belajar }\end{array}$ & 1,2 & 3,4 & 4 \\
\hline & & $\begin{array}{l}\text { Bersemangat dalam melakukan } \\
\text { aktivitas belajar }\end{array}$ & 5 & $6,7,8$ & 4 \\
\hline & Mengarahkan & $\begin{array}{l}\text { Mengutamakan kegiatan belajar dari } \\
\text { pada kegiatan lain }\end{array}$ & 9,11 & 10,30 & 4 \\
\hline & & $\begin{array}{l}\text { Tidak mudah terganggu oleh } \\
\text { kegiatan orang lain }\end{array}$ & 13,14 & 15,16 & 4 \\
\hline & Mempertahankan & Tekun dalam mengerjakan tugas & 17,18 & $19,20,29$ & 5 \\
\hline & & Pantang menyerah & 21,24 & $22,23,25$ & 5 \\
\hline & & $\begin{array}{l}\text { Suka melakukan aktivitas belajar } \\
\text { dalam waktu yang lama }\end{array}$ & $26,27,12$ & 28 & 4 \\
\hline
\end{tabular}

\section{HASIL DAN PEMBAHASAN}

Hasil

Data yang diperoleh dari hasil penelitian ini adalah data hasil belajar IPA siswa kelas V, hasil kuesioner pola asuh orang tua dan hasil kuesioner motivasi belajar siswa kelas V gugus VIII Kecamatan Buleleng yang dijadikan sampel dalam penelitian ini. Pada Tabel 3 akan disajikan rangkuman analisis data yang diperoleh. Setelah mencari analisis deskriptif data memperoleh hasil rata-rata pola asuh orang tua sebesar 119,02, standar deviasi sebesar 9,172, varian sebesar 84,133, nilai minimum 95 dan maksimum sebesar 146, sehingga mendapatkan median sebesar 624,5, dan modus sebesar 345,5. Untuk motivasi belajar mendapat hasil analisis rata-rata sebesar 122,51, standar deviasi 9,463, varian sebesar 89,547, nilai minimum 84 dan maksimum 145 , sehingga mendapat median sebesar 670,61 dan modus sebesar 3,555. Untuk hasil belajar rata-rata nya 75,61 standar deviasinya 11,001 , variannya 121,029 , nilai minimumnya 30 dan maksimumnya 100 . Dari pemaparan rata-rata tersebut dapat didilihat data tersebut diklasifikasikan sangat baik.

Tabel 3. Rangkuman Hasil Analisis Deskriptif Data Penelitian

\begin{tabular}{cccc}
\hline Hasil Analisis & Pola Asuh Orang Tua & Motivasi Belajar & Hasil Belajar \\
\hline Rata-rata & 119,02 & 122,51 & 75,61 \\
Standar Deviasi & 9,172 & 9,463 & 11,001 \\
Varian & 84,133 & 89,547 & 121,029 \\
Minimum & 95 & 84 & 30 \\
Maksimum & 146 & 145 & 100 \\
\hline
\end{tabular}


Dari hasil perhitungan distibusi nilai pola asuh orang tua dapat dilihat sebagian besar skor yang diperoleh responden berada pada interval 116-122 yaitu sebanyak 48 orang (33,56\%) dan adapun hasil klasifikasi skala penilaian lima pada pola asuh ini menunjukan bahwa rerata pola asuh orang tua sebesar 119,02 berada pada data yang tergolong sangat baik. Dari hasil perhitungan distribusi nilai motivasi dapat dilihat pada motivasi belajar besaran skor yang diperoleh responden berada pada interval 116-123 yaitu sebanyak 45 orang $(31,46 \%)$ dan adapun hasil klasifikasi skala penilaian lima motivai belajar yang menunjukan rerata motivasi belajar sebesar 122,79 yang data tersebut tergolong sangat baik. Dari hasil perhitungan distribusi nilai hasil belajar IPA dapat dilihat pada hasil belajar skor yang diperoleh responden berada pada interval 75-83 yaitu sebanyak 48 orang $(33,56 \%)$ dan adapun klasifikasi skala penilaian lima pada hasil belajar yang menunjukan rerata hasil belajar sebesar 75,9 yang data tersebut tergolong sangat baik. Dan selanjutnya akan melakukan uji prasyarat analisis sebelum lanjut ke pengujian hipotesis dengan regresi linier, data yang diperoleh terlebih dahulu dilakukan uji normalitasnya. Hasil pengujian normalitas data hasil belajar IPA, pola asuh orang tua dan motivasi belajar sebagai berikut. Nilai Asymp.Sig (2-tailed) pada pola asuh adalah 0,164>0,05 yang berarti data pola asuh orang tua berdistribusi normal, pada motivasi belajar nilai Asymp.Sig(2-tailed) adalah 0,059>0,05 yang berarti data motivasi belajar berdistribusi normal dan nilai Asymp.Sig(2-taild) pada hasil belajar IPA adalah 0,050>0,05 yang berarti data hasil belajar berdistribusi normal. Kriteria pengujian, jika nilai Asymp.Sig $>0,05$ maka data tersebut normal, dan jika data $<0,05$ maka dinyatakan sebaran data tidak normal. Berdasarkan perhitungan dengan menggunakan Kolmogorov Smirnov, diperoleh data hasil distribusi normal. Setelah melakukan uji normalitas selanjutnya melakukan uji linieritas.

Uji linieritas digunakan untuk mengetahui hubungan antara variabel bebas dengan variabel terikat. Uji linieritas pada penelitian ini dilakukan dengan bantuan SPSS. Pengambilan keputusan dari uji linieritas adalah jika nilai signifikansi (deviation from linearity) $>0,05$, maka terdapat hubungan yang linier antara variabel bebas dengan variabel terikat. Jika nilai signifikansi $<0,05$, maka tidak terdapat hubungan yang linier antara variabel bebas dengan variabel terikat. Pada pola asuh terdapat hasil linieritas sebesar 0,163 maka dapat diartikan data tersebut terdapat hubungan yang linier, selanjutnya pada motivasi belajar sebesar 0,452 sehingga terdapat hubungan yang linier. Setelah dilakukan uji prasyarat dan semua uji prasyarat sudah terpenuhi maka dilanjutkan dengan pengujian hipotesis. Adapun uji yang digunakan adalah uji analisis regresi sederhana dan regresi ganda. Dari hasil analisis variabel pola asuh dan motivasi belajar memberikan hubungan terhadap hasil belajar, apabila nilai sig lebih kecil dari 0,05. Dalam hasil analisis nilai signifikansi pola asuh sebesar 0,049 dan nilai motivasi belajar sebesar 0,029 sehingga seluruh variabel bebas berhubungan terhadap variabel terikat. Jadi terdapat hubungan yang positif antara pola asuh dan motivasi belajar terhadap hasil belajar IPA siswa kelas $\mathrm{V}$ Gugus VIII Kecamatan Buleleng. Hasil analisis koefisien kontribusi secara bersama-sama antara variabel bebas dan variabel terikat yaitu hubungan antara pola asuh orag tua dan motivasi belajar terhadap hasil belajar IPA siswa kelas V Gugus VIII Kecamatan Buleleng yaitu 0,207. Jika dibandingkan dengan taraf dignifikansi 5\%

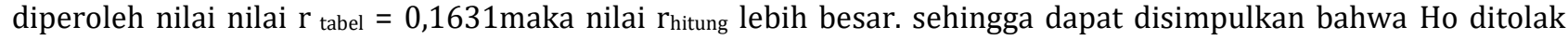
yang berarti terdapat hubungan yang signifikan. Sedangkan koefisien determinasinya yaitu $43 \%$ dari hasil analisis, uji hipotesis secara ringkas disajikan pada Tabel 4.

Tabel 4. Rekapitulasi Hasil Analisis Data pada Uji Hipotesis

\begin{tabular}{cccccc}
\hline Variabel & rhitung & rtabel & $\begin{array}{c}\text { Koefisien } \\
\text { determinasi }\end{array}$ & Ho $_{\mathbf{o}}$ & Hipotesis \\
\hline$r_{x 1 y}$ & 0,908 & 0,1631 & $71 \%$ & Ditolak & Diterima \\
$r_{x 2 y}$ & 0,166 & 0,1631 & $16 \%$ & Ditolak & Diterima \\
$r_{x 1 x 2 y}$ & 0,207 & 0,1631 & $43 \%$ & Ditolak & Diterima \\
\hline
\end{tabular}

Dari hasil perhitungan yang telah dilakukan dan berbagai langkah yang digunakan untuk menganalaisis dan pengujian hipotesis, maka akan dilanjutkan dengan pembahasan hasil penelitian yaitu sebagai berikut. Hipotesis pertama diketahui bahwa terdapat hubungan yang signifikan anatar pola asuh orang tua terhadap hasil belahar IPA siswa kelas V Gugus VIII Kecamatan Buleleng. selain itu nilai korelasi sebesar 0,098 yang dikategorikan memiliki hubungan yang signifikan. Sedangkan kontribusi pola asuh orang tua terhadap hasil belajar sebesar 71\% tergolong cukup tinggi. Tergolong cukup tinggi karena peran orang tua berpengaruh untuk mendampingi anak saat belajar dirumah, anak akan malas belajar jika tidak ditemani atau didampingi orang tua. Oleh karena itu saat belajar dirumah orang tua harus bisa menjadi guru dan teman belajar bagi anak. Namun jika anak sudah dibiasakan mandiri sejak kecil anak tersebut akan belajar secara mandiri tanpa didampingi oleh orang tua. Sikap orang tua dalam berinteraksi, membimbing, membina, dan mendidik dalam kehidupan seharihari menentukan kesuksesan anaknya menjalani kehidupan dan hasil belajar (Juniarti1 et al., 2020). Peran membangun motivasi belajar yang tinggi juga disematkan diatas pundak orangtua (Batoebara \& Hasugian, 2021). Dengan kata lain adanya pola asuh yang baik orang tua akan memberikan pengaruh yang positif terhadap hasil belajar (Sugiartini et al., 2019). Pola asuh orangtua sangat berpengaruh terhadap pertumbuhan dan perkembangan anak baik dari segi fisik, sifat, kepribadian, konsep diri, inteligensi, sosial dan emosional anak 
(Budiarnawan et al., 2014; Tarmidzi, 2018). Bimbingan yang tepat dari pola asuh orang tua dapat meningkatkan motivasi belajar siswa sehinnga tumbuh dorongan dalam diri siswa untuk belajar dengan semangat tinggi menggunakan semua kemampuan dan keterampilan yang dimiliki dirinya (Dewi et al., 2020; Sunarsi, 2018). Jadi, untuk meningkatkan kualitas pembelajaran muatan IPA, pola asuh orangtua dan motivasi siswa sangat berperan penting guna meningkatkan hasil belajar siswa.

Hipotesis kedua diketahui bahwa ada hubungan yang signifikan motivasi dengan hasil belajar IPA siswa kelas V Gugus VIII Kecamatan Buleleng. nilai korelasi sebesar 0,076 dikategotikan memiliki hubungan yang signifikan. Sehingga kontribusi motivasi belajar terhadap hasil belajar sebesar 16\% tergolong rendah. Motivasi tergolong rendah ini dikarenakan orang tua atau lingkungan yang kurang mendukung anak pada saat pembelajaran dirasa memberikan pengaruh, dengan adanya motivasi dirasa sangat penting untuk meningkatkan hasil belajar pada siswa karena perkembangan yang dialami siswa dipengaruhi dengan baik oleh motivasi yang diberikan oleh orang tuanya, sehingga dapat dikatakan dengan dukungan seperti motivasi yang sesuai akan mempengaruhi kecerdasan seorang siswa. Motivasi adalah dorongan yang tumbuh dalam diri seseorang, baik yang berasal dari dalam dan luar dirinya untuk melakukan suatu pekerjaan dengan semangat tinggi menggunakan semua kemampuan dan keterampilan yang dimiliki dirinya (Sunarsi, 2018). Dengan memberikan motivasi belajar pada siswa baik motivasi dari orang tua, guru dan lingkungan akan memberikan pengaruh atau hasil belajar yang sangat penting untuk mengarahkan agar anak dapat melakukan pergaulan yang positif dan berhasil dalam belajar. Motivasi belajar yang tinggi berarti semakin tinggi hasil belajar yang diperoleh siswa (Rizqi \& Sumantri, 2019).

Hipotesis ketiga diketahui bahwa ada hubungan yang signifikan pola asuh orang tua dan motivasi terhadap hasil belajar IPA siswa kelas V Gugus VIII Kecamatan Buleleng. Dengan nilai korelasi yang diperoleh 0,207, dengan kontribusi sebesar $43 \%$ dinyatakan signifikan dan terdapat hubungan yang positif karena pada saat seperti ini adanya pola asuh orang tua yang positif dan motivasi berperan untuk meningkatkan hasil belajar pada siswa karena dengan hal tersebut siswa akan terkontrol dalam melakukan sesuatu, dan memberikan perkembangan yang baik dalam masa belajarnya. Dengan orang tua yang santai dalam mengasuh anak dan memberikan dorongan yang baik untuk anak akan menghasilkan sebuah hubungan yang harmonis dan memberikan hasil belajar yang baik pula. Temuan dalam penelitian ini didukung oleh penelitian yang menyatakan bahwa hubungan yang signifikan antara motivasi belajar dan pola asuh orangtua dengan hasil belajar IPA (Rizqi \& Sumantri, 2019). Motivasi siswa dalam pembelajaran ditunjukkan oleh sikap siswa dalam proses pembelajaran yang meliputi; minat, semangat, tanggung jawab, rasa senang dalam mengerjakan tugas dan reaksi yang ditunjukkan siswa terhadap stimulus yang diberikan guru (Rizqi \& Sumantri, 2019). Faktorfaktor yang mempengaruhi motivasi belajar siswa adalah kemampuan siswa, kondisi lingkungan siswa, dan upaya guru dalam membelajarkan siswa (Moslem et al., 2019; Sabrina et al., 2017).

Penelitian yang menyatakan bahwa terdapat hubungan yang signifikan antara pola asuh orang tua dan motivasi belajar dengan hasil belajar PPKN siswa (Dewi et al., 2020). Jadi, terdapat hubungan yang secara simultan antara pola asuh orang tua dan motivasi belajar terhadap hasil belajar IPA siswa kelas V di Gugus VIII Kecamatan Buleleng. Kelebihan penelitian ini adalah memaparkan informasi mengenai pola asuh, motivasi dan hasil belajar IPA sesuai dengan keadaan pada saat ini. Penelitian yang sejenis mungkin pernah dipaparkan namun setiap tahunnya akan mengalami kendala dan pembaharuan yang berbeda. Hasil penelitian ini sudah memaparkan secara singkat mengenai hasil belajar IPA, pola asuh orang tua, dan motivasi belajar pada siswa, selain itu terdapat hasil penelitian beserta pembahasanya sudah disampaikan secara singkat dan jelas. Penelitian ini dapat dijadikan sebagai pendukung atau rujukan dalam penelitian lain. Bagi peneliti selanjutnya, perlu dilakukan penelitian lanjutan mengenai hubungan pola asuh dan motivasi belajar terhadap hasil belajar, dengan memperluas ruang lingkup penelitian seperti pada aspek psikologis, perkembangan anak dalam proses pembelajaran dan faktor yang mempengaruhi hasil belajar anak agar hasil penelitian yang diharapkan bisa tercapai.

\section{SIMPULAN}

Berdasarkan hasil penelitian dan analisis data statistik maka diperoleh kesimpulan pola asuh orangtua dan motivasi siswa memiliki hubungan dengan hasil belajar siswa. Semakin baik pola asuh yang diberikan orangtua akan mendorong motivasi siswa dalam belajar sehingga akan terjadi peningkatan hasil belajar siswa.

\section{DAFTAR PUSTAKA}

Adawiah, R. (2017). Pola Asuh Orang Tua Dan Implikasinya Terhadap Pendidikan Anak (Studi pada Masyarakat Dayak di Kecamatan Halong Kabupaten Balangan). Jurnal Pendidikan Kewarganegaraan, 7(1), 33-48. http://dx.doi.org/10.20527/kewarganegaraan.v7i1.3534.

Agung, A. A. G. (2014). Metode Penelitian Pendidikan. Aditya Media Publishing.

Anggraini, Hartuti, P., \& Sholihah, A. (2017). Hubungan Pola Asuh Orang Tua Dengan Kepribadian Siswa SMA Di 
Kota Bengkulu. Consilia: Jurnal Ilmiah Bimbingan Dan Konseling, 1(1), 10-18. https://doi.org/10.33369/consilia.1.1.10-18.

Batoebara, M. U., \& Hasugian, B. S. (2021). Peran Orang Tua dalam Komunikasi Pembelajaran Daring. Warta Dharmawangsa, 15(1), 166-176. https://doi.org/10.46576/wdw.v15i1.1058.

Budiarnawan, K. B., Antari, N. N. M., \& Rati, N. W. (2014). Hubungan Antara Konsep Diri Dan Pola Asuh Orang Tua Terhadap Hasil Belajar IPA Siswa Kelas V SD Di Desa Selat. Jurnal Mimbar PGSD Universitas Pendidikan Ganesha, 2(1). http://dx.doi.org/10.23887/jjpgsd.v2i1.2224.

Desta, I. G. B. U., Putri, D. A. W. M., \& Suarni, N. K. (2014). Determinasi Intensitas Pola Asuh Orang Tua Dan Motivasi Berprestasi Terhadap Tingkat Kedisiplinan Siswa Kelas IX SMP Laboratorium Undiksha Singaraja Tahun Pelajaran 2014/2015. Jurnal Ilmiah Bimbingan Konseling Undiksha, 2(1). http://ejournal.undiksha.ac.id/index.php/JJBK/article/view/3938.

Dewi, K. O. R., Murda, I. N., \& Astawan, I. G. (2020). Hubungan Pola Asuh Orang Tua dan Motivasi Belajar Dengan Hasil Belajar PPKN Siswa. Mimbar PGSD Undiksha, 4(1), 53. http://dx.doi.org/10.23887/jjpgsd.v8i1.24578.

Fitasari, N. P. D., Suniasih, N. W., \& Agustika, G. N. S. (2019). Pengaruh Pola Asuh Orang Tua Terhdap Hasil Belajar Matematika dengan Efikasi Diri Sebagai Intervening. International Journal of Elementary Education, 3(4), 404. https://doi.org/10.23887/ijee.v3i4.21313.

Fransisca, I., \& Mintohari. (2018). Pengembangan Media Pembelajaran Video Berbasis Sparkol Videoscribe Pada Pelajaran Ipa Dalam Materi Tata Surya Kelas Vi SD. Jurnal Penelitian Pendidikan Guru Sekolah Dasar, 6(11), 1916-1927. https://jurnalmahasiswa.unesa.ac.id/index.php/39/article/view/24661/22575.

Hewi, L., \& Shaleh, M. (2020). Refleksi Hasil PISA (The Programme For International Student Assesment): Upaya Perbaikan Bertumpu Pada Pendidikan Anak Usia Dini). Jurnal Golden Age, 4(01), 30-41. https://doi.org/10.29408/jga.v4i01.2018.

Juniarti, N. K. R., Margunayasa, I. G., \& Kusmariyatni, N. (2020). Hubungan Antara Pola Asuh Orang Tua dan Konsep Diri dengan Kompetensi Pengetahuan Matematika Siswa. Jurnal Ilmiah Sekolah Dasar, 4(1), 17. https://doi.org/10.23887/jisd.v4i1.24273.

Khodijah, N. (2018). Pendidikan Karakter Dalam Kultur Islam Melayu (Studi Terhadap Pola Asuh Orang Tua, Faktor-Faktor Yang Mempengaruhinya, Dan Pengaruhnya Terhadap Religiusitas Remaja Pada Suku Melayu Palembang). Tadrib: Jurnal Pendidikan Agama Islam, 4(1), 21-39. https://doi.org/10.19109/tadrib.v4i1.1949.

Koyan, I. W. (2012). Statistik Pendidikan Teknik Analisis Data Kuantitatif. Undiksha Press.

Lusidawaty, V., Fitria, Y., Miaz, Y., \& Zikri, A. (2020). Pembelajaran IPA Dengan Strategi Pembelajaran Inkuiri Untuk Meningkatkan Keterampilan Proses Sains Dan Motivasi Belajar Siswa Di Sekolah Dasar. Jurnal Basicedu, 4(1), 168-174. https://doi.org/10.31004/basicedu.v4i1.333.

Machmud, H. (2018). Pengaruh Pola Asuh Terhadap Keterampilan Sosial Anak (Penelitian Expost Facto Pada PAUD Rintisan di Kendari). Jurnal Al-Ta'dib, 11(2), 127-145. http://dx.doi.org/10.31332/atdb.v0i0.1108.

Mahmud, S. N. D., Nasri, N. M., Samsudin, M. A., \& Halim, L. (2018). Science teacher education in Malaysia: challenges and way forward Siti. Asia-Pacific Science Education ORIGINAL, 4(8), 153-155. https://doi.org/10.1186/s41029-018-0026-3.

Maswin, Ilyas, M., \& Nurdin. (2020). Pengaruh Motivasi Berprestasi dan Pola Asuh Orang Tua Terhadap Hasil Belajar Matematika Siswa. Jurnal Penelitian Matematika Dan Pendidikan Matematika, 3(2), 24-30. https://doi.org/10.30605/2615-7667.482.

Meo, L., We'u, G., \& BS, Y. N. (2021). Penerapan Model Pembelajaran Inkuiri Dalam Meningkatkan Hasil Belajar IPA Pada Siswa Sekolah Dasar. Jurnal Ilmiah Pendidikan Citra Bakti, 8(1), 38-52. https://doi.org/10.38048/jipcb.v8i1.97.

Moslem, M. C., Komaro, M., \& Indonesia, U. P. (2019). Faktor-Faktor Yang Menyebabkan Rendahnya Motivasi Belajar Siswa Dalam Mata Pelajaran Aircraft Drawing Di Smk. Journal of Mechanical Engineering Education, 6(2), 258-265. https://doi.org/10.17509/jmee.v6i2.21803.

Prananda, G., Saputra, R., \& Ricky, Z. (2020). Meningkatkan Hasil Belajar Menggunakan Media Lagu Anak Dalam Pembelajaran IPA Sekolah Dasar. JURNAL IKA, 8(2), 304-314. https://doi.org/10.36841/pgsdunars.v8i2.830.

Pucangan, K. Y. J., Suarni, N. K., \& Arini, N. W. (2017). Hubungan antara konsep diri dan pola asuh orang tua terhadap hasil belajar SD kelas II. Jurnal Mimbar PGSD Universitas Pendidikan Ganesha, 5(2), 1-10. http://dx.doi.org/10.23887/jjpgsd.v5i2.11007.

Riski Juniarti1, N. K., Margunayasa, I. G., \& Kusmariyatni, N. (2020). Hubungan Antara Pola Asuh Orang Tua dan Konsep Diri dengan Kompetensi Pengetahuan Matematika Siswa. Jurnal Ilmiah Sekolah Dasar, 4(1), 17. https://doi.org/10.23887/jisd.v4i1.24273.

Rizqi, A. T., \& Sumantri, M. (2019). Hubungan Antara Motivasi Belajar Dan Pola Asuh Orang Tua Terhadap Hasil Belajar IPA. Jurnal Imiah Pendidikan Dan Pembelajaran, 3(2), 145-154. 
http://dx.doi.org/10.23887/jipp.v3i2.18071.

Sabrina, R., Fauzi, \& Yamin. (2017). Faktor-Faktor Penyebab Rendahnya Motivasi Belajar Siswa Dalam Proses Pembelajaran Matematika Di Kelas V Sd Negeri Garot Geuceu Aceh Besar. Jurnal Ilmiah Pendidikan Guru Sekolah Dasar, 2(4), 108-118. http://www.jim.unsyiah.ac.id/pgsd/article/download/7736/3350.

Safitri, Y. A., Baedowi, S., \& Setianingsih, E. S. (2020). Pola Asuh Orang Tua di Era Digital Berpengaruh Dalam Membentuk Karakter Kedisiplinan Belajar Siswa Kelas IV. MIMBAR PGSD Undiksha, 8(3), 508-514. https://doi.org/10.23887/jjpgsd.v8i3.28554.

Sari, R. I. P. (2014). Hubungan Motivasi Belajar dengan Hasil Belajar Siswa Pada Mata Pelajaran IPS Kelas IV di SDN 11 Petang Jakarta Timur. Pedagogik (Jurnal Pendidikan Sekolah Dasar), II(1), 26-32. https://jurnal.unismabekasi.ac.id/index.php/pedagogik/article/view/1237.

Sugiartini, N. K., Pudjawan, K., \& Renda, N. T. (2019). Hubungan Pola Asuh Orang Tua dan Rasa Percaya Diri Terhadap Hasil Belajar IPA Kelas V. Mimbar PGSD, 5(2), 171. https://doi.org/10.23887/ika.v17i2.19853.

Sugiyono. (2010). Metode Penelitian Pendidikan Pendekatan Kuantitatif, Kualitatif, dan R\&D (Cetakan Ke). Alfabeta.

Sunarsi, D. (2018). Pengaruh Disiplin, Motivasi, Dan Kompetensi Terhadap Prestasi Belajar (Studi Kasus Pada Mahasiswa Universitas Pamulang, Tangerang Selatan Tahun Akademik 2016-2017). Jurnal Mandiri, 1(2), 207-226. https://doi.org/10.33753/mandiri.v1i2.19.

Tarmidzi. (2018). Hubungan Pola Asuh Orang Tua dengan Psychological Self Concept Anak Dalam Kegiatan Pembelajaran di Sekolah Dasar. Caruban: Jurnal Ilmiah Ilmu Pendidikan Dasar, 1(1), 23. https://doi.org/10.33603/caruban.v1i1.1167.

Widiantari, N. L., \& Suarjana, I. M. (2020). Hubungan Antara Pola Asuh Orang Tua Dengan Hasil Belajar IPA siswa kelas V. Edukasi: Jurnal Penelitian Dan Artikel Pendidikan, 25(2), 85-94. https://doi.org/10.31603/edukasi.v12i2.4196.

Wulandari, A. P., \& Renda, N. T. (2020). Hubungan Antara Pola Asuh Orang Tua dengan Motivasi Belajar Matematika Siswa. Mimbar Ilmu, 25(2), 90. https://doi.org/10.23887/mi.v25i2.26068. 